\title{
THE CONFRONTATION BETWEEN STATE COMPULSORY MEDICAL MALPRACTICE SCREENING STATUTES AND FEDERAL DIVERSITY JURISDICTION
}

In recent years legislatures in many states have enacted statutes requiring plaintiffs in medical malpractice actions to present their claims to a review board or screening panel before commencing legal proceedings in the appropriate court of law. The screening panel receives evidence regarding the malpractice claim, and only after the panel has issued its conclusions may the malpractice plaintiff begin customary legal proceedings. The question arises whether a federal court, exercising diversity jurisdiction, is bound by these state inedical inalpractice screening requirements and therefore must dismiss the coinplaint of a plaintiff who has not comphed with them. Most federal courts that have faced the issue have interpreted Erie Railroad $v$. Tompkins ${ }^{1}$ and its progeny ${ }^{2}$ to require that the medical malpractice

1. 304 U.S. 64 (1938). Erie held that the Rules of Decision Act required federal courts in diversity actions to apply not only the appropriate state statutes but also the appropriate judicially created common law of the state. The Court determined that it was unconstitutional for the federal courts to ignore the law created by the state courts and to declare its own "substantive rules of common law applicable in a State." 304 U.S. at 78.

The Rules of Decision Act provides: "The laws of the several states except where the Constitution or treaties of the United States or Acts of Congress otherwise require or provide, shall be regarded as rules of decision in civil actions in the courts of the United States, in cases where they apply." 28 U.S.C. \& 1652 (1976).

2. The Supreme Court cases interpreting Erie include Hanna v. Plumer, 380 U.S. 460 (1965); Byrd v. Blue Ridge Rural Elec. Coop., 356 U.S. 525 (1958); Woods v. Interstate Really Co., 337 U.S. 535 (1949); Guaranty Trust Co. v. York, 326 U.S. 99 (1945).

The Court in Guaranty Trust held that if an action would be barred in a state court by the state statute of limitations, a federal court could not take cognizance of it in a diversity action. Guaranty Trust maintained that

in all cases where a federal court is exercising jurisdiction solely because of the diversity of citzenship of the parties, the outcome of the litigation in the federal court should be substantially the same, so far as legal rules can determine the outcoine of a litigation, as it would be if tried in a State court.

Id. at 109. A statute of linitations that would bar recovery completely in a state court action "so intimately affect[s] recovery or non-recovery" that a federal court inust follow the statute in a diversity case. Id. at 110 .

In Woods, the court held that when Mississippi law voided a contract because one of the parties thereto was doing business in Mississippi without being qualified to do so under a Mississippi statute, a federal court in that state could not enforce the contract. The Woods court declared that the Guaranty Trust case 
complaint not be heard until the plaintiff has followed the state's mandatory review procedure. ${ }^{3}$

This Comment will begin with an introduction to various state inedical malpractice review statutes and a statement of the dilemma faced by federal diversity courts sitting in states with such statutes. The Comment will argue that the holding of the inajority of the courts is unsound, and that the Erie line of cases, as well as the supremacy of federal diversity jurisdiction, frees the federal courts froin the obligation to yield to the mandates of state inedical malpractice screening systems.

was premised on the theory that a right which local law creates but which it does not supply with a remedy is no right at all for purposes of enforcement in a federal court in a diversity case; that where in such cases one is barred from recovery in the state court, he should likewise be barred in the federal court.

337 U.S. at 538.

In Byrd, the court held that despite South Carolina state court decisions that the court should determime whether a plaintiff is an employee of the defendant for purposes of the state's Workmen's Coinpensation Act, the plaimtiff in a federal court diversity action is entitled to have the issue decided by a jury. The Supreme Court could find "nothing to suggest that [the South Carolina] rule was announced as an integral part of the special relationship created by the statute." 356 U.S. at 536. The requirement that a judge determine the issue was "merely a form and mode of enforcing the [Workmen's Compensation Act] immunity . . . and not a rule intended to be bound up with the definition of the rights and obligations of the parties." Id. The outcome of a personal imjury case might be substantially affected, see Guaranty Trust Co. v. York, 326 U.S. at 109-10, by whether the issue of immunity is decided by a judge or a jury. Byrd v. Blue Ridge Rural Elec. Coop., 356 U.S. at 537. However, "the federal pohicy favoring jury decisions of disputed fact questions, . . . [characterized by the court as a "countervailing consideration," should not] yield to the state rule in the interest of furthering the objective that the litigation should not come out one way in federal court and another way in the state court." Id. at 538.

In Hanna, the Court held that in a diversity case, service of process should be subject to the standards of FED. R. CIV. P. 4(d)(1) rather than to the state law requirements. The Court noted that the "outcome-determmation" test of Guaranty Trust "cannot be read without reference to the twin aims of the Erie rule: discouragement of forum-shopping and avoidance of inequitable administration of the laws." 380 U.S. at 468. Under the facts of Hanna, the plaintiff, in choosing between the federal and the state forums, was not facing a situation where application of the state rule would wholly bar recovery; abiding by state law would mean just a mimor change in the way in which process was served. Moreover, permitting service upon the defendant's wife rather than requiring in-hand service under state law does not alter "the mode of enforcement of state-created rights" to a degree necessary to raise the Erie concern of inequitable administration of the laws. Id. at 469.

3. See Edelson v, Soricelli, Nos. 78-2627 \& 79-1012 (3d Cir. Nov. 2, 1979); Woods v. Holy Cross Hosp., 591 F.2d 1164 (5th Cir. 1979); Seoane v. Ortho Pharmaceuticals, Inc., 472 F. Supp. 468 (E.D. La. 1979); Himes v. Elkhart Gen. Hosp., 465 F. Supp. 421 (N.D. Ind.), aff d, 603 F.2d 646 (7th Cir. 1979); Davison v. Simai Hosp. of Baltimore, Inc., 462 F. Supp. 778 (D. Md. 1978); Wells v. McCarthy, 432 F. Supp. 688 (E.D. Mo. 1977); Marquez v. Hahnemann Medical College \& Hosp., 435 F. Supp. 972 (E.D. Pa. 1976); Flotemersch v. Bedford County Gen. Hosp., 69 F.R.D. 556 (E.D. Tenn. 1975). But see Edelson v. Soricelli, Nos. 78-2627 \& 79-1012 (3d Cir. Nov. 2, 1979) (Rosenn, J., dissentimg); Wheeler v. Shoemaker, 78 F.R.D. 218 (D.R.I. 1978). 


\section{Compulsory Medical Malpractice Screening Panel STATUTES}

In response to the increasing number of medical malpractice claims and the consequent rise in inalpractice insurance rates, ${ }^{4}$ many state legislatures have enacted statutes requiring preliminary review of malpractice allegations. ${ }^{5}$ The legislatures have apparently perceived shortcomings in the jury trial as a means of resolving medical malpractice claims. Jury trials increase the cost of malpractice insurance; the slowness of jury trials forces patients, who desperately need money to pay inedical bills, to settle for less than their claims are worth; and the

4. See Redish, Legislative Response to the Medical Malpractice Insurance Crisis: Constitutional Implications, 55 TEx. L. REv. 759, 759-60 (1977). See generally Margolick, Mediation Isn't Cure for Patients' Claims, Nat'l L.J., Feb. 4, 1980, at 1, col. 1.

5. See Alaska Stat. $§ \S 09.55 .535-560$ (Michie Supp. 1979); Ariz. Rev. Stat. ANn. $\$ \S 12$ 561 to -569 (West Supp. 1979); Del. Code AnN. tit. 18, $\$ \S 6801-6821$ (Michie Supp. 1978); Fla. Stat. ANn. § 768.40-.51 (West Supp. 1978); Hawall Rev. STat. $\$ \$ 671-1$ to -20 (Supp. 1979); IDAHO CODE §§ 6-1001 to-1013 (Bobbs-Merrill 1979 \& Supp. 1979); IND. CoDE ANN. §§ 16-9.5-91 to -10 (Burns Supp. 1979); LA. Rev. Stat. ANn. § 40:1299.47-.48 (West 1977 \& Supp. 1980); MD. CTs. \& Jud. Proc. Code AnN. §§ 3-2A-01 to -09 (Michie Supp. 1980); Mo. AnN. Stat. $\S \S 538.010-.055$ (Vernon Supp. I980); MoNT. REv. CODEs ANN. $\S \S 17-1301$ to -1315 (Allen Smith Supp. 1977); Nev. Rev. STAT. § 41A.010-.120 (1977); N.M. STAT. ANN. §§ 41-5-1 to -28 (Michie I978); N.D. Cent. Code § 32-29.1-01 to -10 (Allen Smith Supp. 1979); PA. Stat. ANn. tit. 40, $\S \S 1301.301-.606$ (Purdon Supp. 1979-1980); R.I. GEN. LAws $\$ \S 10-19-1$ to -10 (Bobbs-Merrill Cum. Supp. 1978); TENN. CODE ANN. \$§ 23-3401 to -3421 (Bobbs-Merrill Supp. 1979); VA. CodE $\$ \S 8.01-581.1$ to $-.12: 2$ (Michie 1977 \& Supp. 1979).

Provisions in state medical malpractice review statutes have raised federal and state constitutional issues. See generally Redish, supra note 4. The Florida Supreme Court has ruled that the state's medical malpractice screening statute limiting the jurisdiction of the mediation panel to ten months violates the due process clauses of the United States and the Florida Constitutions. Aldana v. Holub, Nos. 53,612 \& 53,227 (Fla., Feb. 28, 1980). The Supreme Court of Missouri has held that the Missouri screening statute violates art. I, $\S 14$ of the Missouri Constitution by limiting access to the state courts. State ex rel. Cardinal Glennon Memorial Hosp. for Children v. Gaertner, 583 S.W.2d 107 (Mo. 1979). In Eastin v. Broomfield, 116 Ariz. 576, 570 P.2d 744 (1977), the Supreme Court of Arizona concluded that a provision of the Arizona Medical Malpractice Act that required the nonprevailing party before the review panel to post a bond before procecding to trial violated the Arizona Constitution's privileges and immunities clause, ARIz. CONST. art. 11, $\S 13$. Other provisions of state medical malpractice review statutes have withstood constitutional challenge. See, e.g., Woods v. Holy Cross Hosp., 591 F.2d 1164 (5th Cir. 1979) (Fla. statute); Seoane v. Ortho Pharmaceuticals, Inc., 472 F. Supp. 468 (E.D. La. 1979) (La. statute); Hines v. Elkhart Gen. Hosp., 465 F. Supp. 421 (N.D. Ind.), affd, 603 F.2d 646 (7th Cir. 1979) (Ind. statute); Davison v. Sinai Hosp. of Baltimore, Inc., 462 F. Supp. 778 (D. Md. 1978) (Md. statute); Eastin v. Broomfield, 116 Ariz. 576, 570 P.2d 744 (1977) (Ariz. statute); Carter v. Sparkman, 335 So. 2d 802 (Fla. 1976) (Fla. statute), cert. denied, 429 U.S. 1041 (1979); Butler v. Flint-Goodridge Hosp. of Dillard Univ., 354 So. 2d 1070 (La. Ct. App. 1978) (La. statute); Attorney Gcn. of Md. v. Johnson, 282 Md. 274, 385 A.2d 57 (Md. statute), appeal dismissed, 439 U.S. 805 (1978) (dismissed for want of substantial federal question); Parker v. Children's Hosp. of Philadelphia, 483 Pa. 106, 394 A.2d 932 (1978) (Pa. statute). 
lack of predictability of jury verdicts makes it difficult to pursue an intelligent settlement strategy. ${ }^{6}$

State legislatures created screening panels to provide a quick pretrial review of medical malpractice claims. ${ }^{7}$ This review is designed to prevent malpractice actions against health care providers from being filed in court when "the facts do not permit at least a reasonable inference of malpractice."8 Another purpose of the screening panel requirement is to encourage settleinent. By giving the parties a preliminary view of the merits of the case, the review panel procedure aids them in negotiatimg a settlement. Indeed, it puts them under pressure to settle. ${ }^{9}$ Settlement of a malpractice claim reduces litigation costs and avoids submission of the neghigence issue to a jury; jury verdicts, often "allegedly ill-founded or unreasonable," 10 are believed to be much higher than settlement figures. ${ }^{11}$ Furthermore, proceedings before a screening panel and consequent settlement also avoid or minimize publicity that

6. See Comment, An Analysis of State Legislative Responses to the Medical Malpractice Crisis, 1975 DUKE L.J. 1417, 1455.

7. See id. 1456. The Pennsylvauia legislature, for example, has declared that its purpose was "to establish a system through which a person who has sustained injury or death as a result of tort or breach of coutract by a health care provider can obtain a proinpt determination and adjudication of his claim and the determmation of fair and reasonable compensation." PA. STAT. ANN. tit. 40, § 1301.102 (Purdon Supp. 1979-1980); see Mo. ANN. STAT. § 538.020(3) (Vernon Supp. 1980); TENN. Code ANN. § 23-034030 (Bobbs-Merrill Supp. 1979).

8. Mont. Rev. Codes Ann. § 17-1302 (Allen Smith Supp. 1977); see Berkman, Alternatives to Medical Malpractice Litigation, 12 ForUM 479, 487 (1977); Project, Medical-Legal Screening Panels as an Alternative Approach to Medical Malpractice Claims, 13 WM. \& MARY L. REv. 695, 705 (1972).

9. Coinment, supra note 6, at 1456.

10. Berkman, supra note 8, at 479.

11. Redish, supra note 4, at 767 . The medical malpractice plaintiff and defendant who ultinately appear before a screening panel will still incur legal expeuses for the fees of attorneys who prepare their cases and represent them before the panel. Nonetheless, if the review proceedings are conducted inore expeditiously than ordinary litigatiou, and ordinary litigation does not follow the review proceedings, expenses of the parties will be reduced. If the parties resort to ordinary litigation after coinpletion of the review process, however, the legal fees associated with ordinary malpractice litigation are increased by the addition of the review stage.

The parties appearing before a medical malpractice review panel may also be liable for the costs of administering the review panel progran. In some states, review pauels are funded by assessments on health care providers who practice in the state. See, e.g., PA. STAT. ANN. tit. 40, $\$ 1301.304$ (Purdon Supp. 1979-1980). Under other statutes, both parties bear the review panel expenses. See, e.g., Fla. Stat. Ann. \& 768.44(2)(i) (West Supp. 1978); VA. Code $\$ 8.01-581.10$ (Michie 1977 \& Supp. 1979). Other plans for funding review panels include the imposition of panel costs on the party in whose favor the panel decides, see, e.g., LA. REv. StAT. ANN. \& 40:1299.47 (West 1977 \& Supp. 1980), or giving the panel authority to assess costs up to a certain anount on the party against whom the panel opinion is rendered, see, e.g., DEL. CODE ANN. tit. $18, \S 6813$ (Michie Supp. 1978). The review panel may even be finauced by a tax on malpractice insurers. See, e.g., Mo. ANN. STAT. $\$ 538.055$ (Vernon Supp. 1980). Arizona has provided that the panel expenses shall be paid by the state out of funds appropriated for the purpose. ARIz. Rev. STAt. ANN. § 12-567(M) (West Supp. 1979). 
might harm the professional reputation of the malpractice defendant. ${ }^{12}$

Most state statutes require that the plaintiff undergo the screening process even before he files suit. ${ }^{13}$ The screening panel is normally coinposed of nembers of the medical and legal professions ${ }^{14}$ who are selected in a process that frequently involves the court, medical and legal professional organizations, and the parties themselves. ${ }^{15}$

The inedical malpractice screening system has many of the attributes of a civil judicial proceeding. The panel receives written evidence from the parties ${ }^{16}$ and listens to oral testimony of witnesses under oath during a hearing. ${ }^{17}$ The panel usually has the right to coinpel the attendance of witnesses and the production of evidence. ${ }^{18}$ The screening panel statutes often give the parties the rights of discovery they would enjoy in an ordinary civil suit. ${ }^{19}$ In some states, the rules of evidence must be observed in the hearings before the panel; ${ }^{20}$ in others, the evidence rules are relaxed.21 Other elements of a traditional trial, such as pleadings, ${ }^{22}$ opening and closing statements, ${ }^{23}$ and cross-exammation, ${ }^{24}$ are utilized under several of the state plans. In addition, many of the statutes give the panel authority to appoint expert inedical witnesses to aid in understanding the case. ${ }^{25}$

Soinetime after the conclusion of the hearing the screening panel - issues a report of its findings. The decision of the panel can take any of several forms, but generally there is a ruling on the issue of the defend-

12. Berkman, supra note 8, at 487; Redish, supra note 4, at 767; Project, supra note 8, at 705.

13. See, e.g., Fla. Stat. ANN. \& 768.44(1)(a) (West Supp. 1978).

14. See, e.g., N.M. STat. ANn. \& 41-5-17(D) (Michie 1978).

15. See, e.g., N.D. CENT. Code $\$ 32.29 .1-04$ (Allen Smith Supp. 1979). Under the North Dakota system the state medical association compiles a list of physicians who are licensed to practice im the state. The state bar association compiles a similar list of attorneys. The malpractice claimant and potential defendant each nominate one physician and one attorney to serve on the panel. Either party may challenge a nomination without cause. The party whose nominee has been challenged then selects another nominee. If two or more challenges are made, the judge compiles a hist of three physicians or attorneys, from which each party strikes one name. The remaining physician or attorney becomes the nominee. The physicians and attorneys selected then nommate, from a list coinpiled by the court, a citizen member to serve on the panel. Finally, the judge appoints the nommees to serve on the panel. Id.

16. See, e.g., ARIZ. Rev. STat. ANN. \& 12-567(D) (West Supp. 1979).

17. See, e.g., Del. Code ANN. tit. 18, \& 6808 (Michie Supp. 1978).

18. See, e.g., HawaII Rev. Stat. §671-13 (Supp. 1979).

19. See, e.g., Md. Cts. \& Jud. Proc. Code AnN. \& 3-2A-05(b) (Michie Supp. 1980).

20. See, e.g., PA. Stat. ANN. tit. 40, § 1301.307(a) (Purdon Supp. 1979-1980).

21. See, e.g., VA. CODE § 8.01-581.6(2) (Michie 1977 \& Supp. 1979).

22. See, e.g., MD. CTs. \& Jud. Proc. CODE ANN. § 3-2A-04(a) (Michie Supp. 1980).

23. See, e.g., ARiz. Rev. Stat. ANN. \& 12-567(E) (Wcst Supp. 1979).

24. See, e.g., FiA. STAT. ANN. \& 768.44(6) (West Supp. 1978).

25. See, e.g., R.I. GEN. LAws $\S 10-19-5$ (Bobbs-Merrill Cum. Supp. 1978). 
ant's negligence. ${ }^{26}$ Upon a finding of negligence the screening panel is frequently required or permitted to reach a conclusion as to the extent of the plaintiffs injuries or monetary damages. ${ }^{27}$

The statutes generally provide that either party may reject the findings of the review board. ${ }^{28}$ Upon rejection of the findings, the medical malpractice plaintiff may begin his traditional lawsuit in a court of general jurisdiction. ${ }^{29}$ The statutes differ on the question of the admissibility of the panel's findings into evidence. ${ }^{30}$ Regardless of the findings of the screening panel, and whether or not they are admissible in evidence in subsequent malpractice litigation, the plaintiff may proceed with a traditional trial that determines de novo the issue of the defendant's liability and the plamtiff's damages.

\section{Federal Courts and State Screening Requirements: The MAJORITY VIEW}

Assume that State $A$, the doinicile of a medical malpractice defendant, has a compulsory medical malpractice screening panel statute. The plaintiff, a citizen of State $B$, brings his action in a federal district court sitting in State $A$, alleging danages that exceed $\$ 10,000$. The plaintiff has not complied with the screening requirement of State $A$ 's statute, the applicable law. On the basis of the plaintiffs failure to submit his complaint to the screening panel for initial review, the defendant moves that the court dismiss the plaintiff's complaint. The defendant argues that the Erie doctrine ${ }^{31}$ requires a federal district court, exercising diversity jurisdiction, to confornn to the applicable state malpractice review statute. Accordingly, he argues, the federal court must decline to hear the case until the parties have undergone the screening process. In opposition the plaintiff argues that the Erie doctrime does not require the federal court to obey the mandates of the state statute. This, then, is the issue presented to the federal courts: whetler Erie and its progeny compel federal courts exercising diversity

26. The state statutes typically require the panel to determine whether or not "the evidence supports the conclusion that the defendant or defendants failed to meet the appropriate standard of care." LA. Rev. Stat. AnN. § 40:1299-47(G) (West 1977 \& Supp. 1980).

27. See, e.g., Mo. AnN. Stat. $\$ 538.045$ (Vernon Supp. 1980). Contra, Nev. Rev. Stat. § 41A.060(2) (1977).

28. See, e.g., TENN. CodE ANN. § 23-3403(d) (Bobbs-Merrill Supp. 1979).

29. Id.

30. See, e.g., ALASKa STAT. \& 09.55.536(e) (Michie Supp. 1979) (report of panel is admissible in evidence); Mo. ANN. STAT. $\$ 538.050$ (Vernon Supp. 1980) (recommendations of review board are not adinissible in evidence).

31. See notes 1 \& 2 supra. 
jurisdiction to comply with state medical malpractice compulsory review statutes.

The great majority of the federal courts that have faced this question have held that a medical malpractice plaintiff desiring to sue in federal court must pass through the state-mandated screening procedure before commencing litigation. ${ }^{32}$ The courts adopting this view have einployed several rationales derived from Erie and its progeny. First, the decisions have noted that "tlie pohcy underlying the Erie doctrine is to elimmate discrimination agamst citizens of the state and to discourage forum shopping." 33 If federal diversity courts did not require inedical malpractice plaintiffs to comply. with the screening procedure, the result would be discrimination in favor of nonresidents. ${ }^{34}$ "Plaintiffs in diversity actions would have a definite and significant advantage not available to state court plaintiffs. This advantage . . . would encourage foruin shopping between the state and federal judicial systems. Such a result is incompatible with Erie." 35 This discrimination and forum-shopping rationale seems to be derived from a sentence in Hanna v. Plumer ${ }^{36}$ and from dicta in Erie. ${ }^{37}$

The second Erie-type rationale on which the majority-rule courts have based their decision is the "door-closing" doctrine. This doctrine "precludes inaintenance im the federal courts of suits to which the state has closed its courts." 38 Simce the state court would close it doors to the same medical malpractice action, "at least until the arbitration proceeding required by law is completed,"39 "that saine result should obtain when suit is filed in federal court." 40 This rationale is derived from

32. See cases cited in note 3 supra.

33. Wells v. McCarthy, 432 F. Supp. 688, 689 (E.D. Mo. 1977); see Edelson v. Soricelli, Nos. 78-2627 \& 79-1012, ship op. at 22 (3d Cir. Nov. 2, 1979); Woods v. Holy Cross Hosp., 591 F.2d 1164, 1170 (5th Cir. 1979); Marquez v. Hahnemann Medical College and Hosp., 435 F. Supp. 972, 973 (E.D. Pa. 1976).

34. Edelson v. Soricelli, Nos. 78-2627 \& 79-1012, slip op. at 22 (3d Cir. Nov. 2, 1979); Wells v. McCarthy, 432 F. Supp. 688, 689 (E.D. Mo. 1977).

35. Edelson v. Soricelli, Nos. 78-2627 \& 79-1012, slip op. at 22 (3d Cir. Nov. 2, 1979); see Woods v. Holy Cross Hosp., 591 F.2d 1164; 11168 (5th Cir. 1979).

36. 380 U.S. 460,468 (1965) ("The 'outcome-determination' test therefore cannot be read without reference to the twim aims of the Erie rule: discouragement of forum-shopping and avoidance of inequitable administration of the laws"). For a general description of Hanna, see note 2 supra.

37. Swift v. Tyson introduced grave discrimination by non-citizens against citizens. It made rights enjoyed under the unwritten "general law" vary according to whether enforcement was sought in the state or in the federal court; and the privilege of selecting the court in which the right should be determined was conferred upon the noncitizen.

Erie R.R. v. Tompkins, 304 U.S. 64, 74-75 (1938).

38. Marquez v. Hahnemann Medical College \& Hosp., 435 F. Supp. 972, 973 (E.D. Pa. 1976).

39. Id.

40. Wells v. McCarthy, 432 F. Supp. 688, 689 (E.D. Mo. 1977); see Edelson v. Soricelli, Nos, 78-2627 \& 79-1012, slip op. at 6 (3d Cir. Nov. 2, 1979). 
the Supreme Court's holding in Woods v. Interstate Realty Co. ${ }^{41}$ that a contract that was void or unenforceable in Mississippi courts could not be enforced by a federal diversity court in Mississippi. "[W] such cases one is barred from recovery in the state court, he should likewise be barred in the federal court." 42

The court in Davison v. Sinai Hospital of Baltimore, Inc. ${ }^{43}$ basing its decision on a sentence from the Supreme Court's opinion in Hanna ${ }^{44}$ held that under the Erie doctrine, the "cliaracter" of hitigation of a state claim in federal court must not materially differ froin the cliaracter of litigation of the same claim in a state court. The absence of the screening process from federal litigation would constitute such a material difference.

It is clear that the character of litigation would differ drastically if plaintiffs in Maryland state courts were required to submit their claims to an arbitration panel prior to bringing suit and plaintiffs in this court were not. Such a difference inay or inay not ultimately affect the result or outcome of the litigation. It certainly does, however, change the nature of the initial stages of the litigation and ultimately of the trial, given that the findings of the panel are admissible in a trial de novo. 45

Two courts requiring plaintiffs' compliance with the screening panel procedures liave cliaracterized the completion of sucli procedure as a condition precedent to enforcement of the inedical malpractice claim against the defendant. ${ }^{46}$

Finally, federal courts examining the apphicability of inedical malpractice review requirements liave interpreted Erie as a prohibition of

41. 337 U.S. 535 (1949).

42. $I d$. at 538 .

43. 462 F. Supp. 778 (D. Md. 1978).

44. "The Erie rule is rooted in part in a realization that it would be unfair for the character or result of a litigation materially to differ because the suit had been brought in a federal court." Hanna v. Plumer, 380 U.S. at 467, quoted in Davison v. Sinai Hosp. of Baltimore, Inc., 462 F. Supp. at 780 (emphasis added). For a general description of Hanna, see note 2 supra.

45. $462 \mathrm{~F}$. Supp. at 780 . There are apparently no other federal decisions explaining or particularly employing the phrase, "character . . . of a litigation," which appears in the Hanna opinion, 380 U.S. at 467 . It appears, then, that the phrase, as unessential dictum, has had little precedential force in Erie cases.

46. The court in Flotemersch v. Bedford County Gen. Hosp., 69 F.R.D. 556 (E.D. Tenn. 1975), held that "the plaintiff was required to demonstrate that the prerequisites for relief under the Tennessee Medical Malpractice Review Board and Claims Act of 1975 . . . were satisfied or have been excused. ..."Id. at 557 . In that case the statutory condition precedent had not been performed. Id. The Third Circuit has described the Pennsylvania inalpractice screening requirement as "a condition precedent to entry into the state judicial system." Edelson v. Soricelli, Nos. 78-2627 \& 79-1012, shp op. at 7 (3d Cir. Nov. 2, 1979) (emphasis added); accord, Hines v. Elkhart Gen. Hosp., 465 F. Supp. 421, 425 (N.D. Ind.), affd, 603 F.2d 646 (7th Cir. 1979) (Indiana screening requirement described as a "statutory condition of precedent to the filing of malpractice claims within the diversity judisdiction of this Court"). 
federal court interference with a state legislature's attempt to achieve a legitimate objective. If out-of-state plaintiffs were able to prosecute their medical unalpractice claims in federal court without passing the review panel hurdle, the state's ability to achieve its goal of reducing the occurrence of high jury verdicts and harmful publicity would be frustrated. 47

Courts, then, have relied on dicta extracted from the text of the opimons of Erie and its progeny. Even when the very general dicta of the Erie line of cases provide the only guidance in this area, these courts fail to acknowledge the potential contrary result that other plausible interpretations of the dicta would indicate. More important, the courts ignore the strong federal interest in preserving the federal courts' diversity jurisdiction from erosion by state-created limitations on the litigation process. The following sections examine in more detail the Erie doctrime, consider the federal interests implicated in state screening requirements, and conclude that the holdings of these courts are erroneous.

\section{Federal Courts and the State Screening Requirements: AN OPPOSING VIEW}

\section{A. The Erie Doctrine. ${ }^{48}$}

A careful reading of Erie Railroad $v$. Tompkins ${ }^{49}$ and subsequent Supreine Court cases ${ }^{50}$ indicates that the Erie doctrime does not compel a federal diversity court to require a medical malpractice plaintiff to complete the screening process before filing his claim. The Erie decision itself focused on two central considerations. First, the Court found

47. The Fifth Circuit has addressed the problem of federal court interference with Florida's proposal for reducing the costs associated with malpractice litigation and liability.

As we have observed, the Florida Legislature acted in 1975 to avert what it viewed as an impending crisis in the health care field. An integral part of its action was to require malpractice claimants to subunit their claims to mediation, "thereby reducing the cost of medical malpractice insurance and ultimately medical expenses. ..." We would do grave dainage to the legislative response evidenced by Florida's Medical Malpractice Law if we refused to apply the mediation requirement in diversity cases. We decline to take such a step.

Woods v. Holy Cross Hosp., 591 F.2d 1164, $1168-69$ (5th Cir. 1979) (quoting Carter v. Sparkman, 335 So. 2d 801, 809 (Fla. 1976)); see Marquez v. Hahnemaim Medical College \& Hosp., 435 F. Supp. 972, 974 (E.D. Pa. 1976) ("By statute . . . , Pennsylvania has attempted to deal with the inedical malpractice crisis that confronts the commonwealth and the nation. The Pennsylvania legislature has decided that compulsory arbitration may ameliorate this crisis. This court will not interfere with such expression of legislative intent"). For the source of this "noninterference rationale," see text accompanying note 53 infra.

48. See generally Turner, Medical Malpractice Arbitration on the Erie Railroad, 11 U. TOLedo L. REV. 1 (1979).

49. 304 U.S. 64 (1938).

50. See note 2 supra. 
it necessary to end the Swift $v$. Tyson ${ }^{51}$ tradition of federal, judge-made law in diversity cases because it had created "grave discrimination by non-citizens agamst citizens." 52 Second, the Erie Court believed that a federal court's failure to heed the state's judicially created law as well as its statutory law in enforcing state-created rights in diversity suits "invaded rights which . . . are reserved by the Constitution to the several states."53

It is uncertain that the failure of a federal court to dismiss the claim of a plaintiff who has not obtained a decision from the stateordamed review board would introduce the kind of grave discrimmation that worried the Erie Court or would constitute an invasion of state rights. Erie's Supreme Court progeny support the proposition that federal courts are not obliged to dismiss malpractice suits that have not passed through a state-mandated review procedure. These decisions have distinguished between state laws that create or are bound up with rights and obligations and those that control the forms, inode, manner, and means of enforcing such rights and obligations. ${ }^{54}$ Federal courts must heed the former category of state law, but are free to ignore the latter.

Beyond this dichotoiny, the Court has developed several subsidiary tests for use in Erie questions. In Guaranty Trust Co. v. York, ${ }^{55}$ the Supreme Court declared that when the applicability of a state statute in a federal diversity action arises,

[t] he question is whether such a statute concerns merely the manner and means by which a right to recover, as recognized by the State, is enforced, or whether such statutory limitation is a matter of substance in the aspect that alone is relevant to our problem, namely does it significantly affect the result of a litigation for a federal court to disregard a law of a State that would be controlling in an action upon the same claim by the same parties in a State court? ${ }^{56}$

5I. 41 U.S. (16 Pet.) I (1842).

52. 304 U.S. at 74. The nonresident plaintiff who met the requirements of diversity jurisdiction had the privilege of choosing the federal court, where the unwritten "general law" would apply, or the state court, where the state courts' decisions would determine the issue. Resident plaintiffs had no such choice.

53. Id. at 80. The Court suggested there had been a violation of the tenth amendment, U.S. Const, amend. $\mathrm{X}$.

54. A federal court should apply the state rule "if the choice of rule would substantially affect those primary decisions respecting huinan conduct which our consitutional system leaves to state regulation." Hanna v. Plumer, 380 U.S. 460, 475 (I965) (Harlan, J., concurring). The federal court inust determine whether the state requirement is "a rule intended to be bound up with the definition of the rights and obligations of the parties" or "merely a form and mode of enforcing [such] . . . rights and obligations." Byrd v. Blue Ridge Rural Elec. Coop., 356 U.S. 525, 536 (1958).

55. 326 U.S. 99 (1945)

56. Id, at 109 . 
Another subsidiary rule derived from Erie provides that when a plaintiff would be barred from recovering on a cause of action in state court, he must also be barred in a diversity action in a court sitting in that state. ${ }^{57}$ A third auxiliary Erie standard was developed in Byrd v. Blue Ridge Rural Electrical Cooperative:58 even if a state rule bears substantially on the question whether litigation would come out one way in the federal court and another way in the state court, if the federal court fails to apply the rule, state statutes should not be permitted to "disrupt or alter the essential character or function of a federal court." 59

In an effort to mcorporate the rules and distimctions developed under Erie and its progeny, two federal courts of appeals have devised tests for the apphication of state law in federal diversity actions. ${ }^{60}$ The inore recent of these tests was developed by Judge Celebrezze in Miller v. Davis: 61

1. If the state provision is the substantive right or obligation being asserted, the federal court must apply it.

2. If the state provision is a procedural rule which is intimately bound up with the substantive right or obligation being asserted, the federal court must apply it.

3. If the state provision is a procedural rule which is not intimately bound up with the substantive right or obligation being asserted, but its application might substantially change the outcome of the litigation, the federal court should determine whether state interests in favor of applying the state rule outweigh countervailing considerations against application of the rule. If the state interests predominate, the state rule should be adopted. ${ }^{62}$

Previously, Judge Sobeloff had created a similar set of directives in

57. Woods v. Interstate Realty Co., 337 U.S. 535 (1949); Angel v. Bullington, 330 U.S. 183, 191-92 (1947); Guaranty Trust Co. v. York, 326 U.S. 99, 108-09 (1945).

[A] right which local law creates but which does not supply with a remedy is no right at all for purposes of enforcement in a federal court in a diversity case; . . . where in such cases one is barred froun recovery in the state court, he should likewise be barred in the federal court.

Woods v. Interstate Realty Co., 337 U.S. at 538.

58. 356 U.S. 525 (1958).

59. Id. at 539 (citing Herron v. Southern Pac. Co., 283 U.S. 91 (1931)). The Byrd Court held that "affirmative countervailing considerations" related to maintaining the federal judiciary as "an independent system for administering justice to litigants who properly invoke its jurisdiction," 356 U.S. at 537, precluded application of a judicially created South Carolina rule. The state rule in Byrd required the judge, not the jury, to determine whether a party was a statutory employer under the South Carolina Workmen's Compensation Act. The Court dccided that application of the South Carolima rule would disrupt "the federal system of allocating functions between judge and jury." Id. at 538. The state rule would not prevail over "the federal policy favoring jury decisions of disputed fact questions." Id.

60. Miller v. Davis, 507 F.2d 308 (6th Cir. 1974) (Celebrezze, J.); Szantay v. Beech Aircraft Corp., 349 F.2d 60 (4th Cir. 1965) (Sobeloff, J.).

61. 507 F.2d 308 (6th Cir. 1974).

62. Id. at 314 . 
Szantay v. Beech Aircraft Corp. ${ }^{63}$ The state medical malpractice screenimg requirements do not amount to a substantive obligation or right. The obligation and right im the context of medical malpractice are the physician's obhigation to exercise due care and the patient's right to recover for damages caused by the physician's failure to exercise that duty. The screening panel procedures do not change this basic relationship. If the plaintiff proves the necessary elements of a cause of action for malpractice, he will recover-regardless of the imposition of the screening panel procedure before trial. Nor can it be said that the screening panel requirement is intimately bound up with the physician's duty to care or the malpractice victim's entitlement to recover damages.64 Since "the requirement appears to be merely a form and mode of enforcing the [obligation and right] . . . and not a rule in-

63. 349 F.2d 60, 63-64 (4th Cir. 1965). See also U.S. Indus., Inc. v. Gregg, 58 F.R.D. 469, 474 (D. Del. 1973). Other federal courts have employed the Szantay test in resolving Erie issues. See Grand Bahama Petroleum Co. v. Asiatic Petroleum Corp., 550 F.2d 1320, 1325 (2d Cir. 1977); Karara v. County of Tazewell, 450 F. Supp. 169, 171-72 (W.D. Va. 1978), affd, 601 F.2d 159 (4th Cir. 1979); Kahn v. Sturgil, 66 F.R.D. 487,490 (M.D.N.C. 1975); Poe v. Marquette Cement Mfg. Co., 376 F. Supp. 1054, 1058 (D. Md. 1974); Smith v. Seaboard Coast Line R.R., 327 F. Supp. 536, 538 (D.S.C. 1971).

64. "In a diversity case, state law defining and himiting . . . primary rights and obligations must be applied under the Erie doctrine, enabling members of society prudently to plan and conduct their affairs, whether their conduct will later be called into question in a state or federal court." Wratchford v. S.J. Groves \& Sons Co., 405 F.2d 1061, 1065 (4th Cir. 1969). The screening panel requirement has nothing to do with "enabling members of a society prudently to plan and conduct their affairs . . . [ [Such a rule] plays no role in the ordering of the affairs of anyone." Id. at 1066; see Note, The Law Applied in Diversity Cases: The Rules of Decision Act and the Erie Doctrine, 85 Y ALE L.J. 678, 696 (1976). Judge Rosenn, dissenting in Edelson v. Soricelli, Nos. 782627 \& 79-1012 (3d Cir. Nov. 2, 1979), characterized the Pennsylvania screening process as "a means of regulating the entry to the courtroom" and "a procedural device for allocating cases within the State of Pennsylvania." Id., slip op. at 33-34. The federal court should not have to refer the plaintiff's malpractice suit to the review panel, because "[t]he substantive legal rights of the parties before the panel and the federal court will be the saine. Only the foruin will differ." Id. But see Cohen v. Beneficial Indus. Loan Corp., 337 U.S. 541, 555-57 (1949). In Cohen, the Court held that a federal court whose jurisdiction was based on diversity must apply a New Jersey statute making the unsuccessful plaintiff in a shareholder's derivative suit liable for reasonable expenses of the defense. The statute also pernitted the corporate defendant to require the plaintiff to give security for payment of such expenses as a condition of prosecuting the suit. The Court noted that the statute "creates a new liability where none existed before" and "conditions the stockholder's action." Id. at 555-56. State medical malpractice review requirements do not create any new liability on the part of the plaintiff in the way the New Jersey statute in Cohen did; the obligation to proceed initially before a review board is substantially different from the monetary hability for the expenses of the opposing party under the New Jersey provision. The indemnity bond that defendant could require under the New Jersey statute-a "condition" to the stockholder's action-is distinguishable from the inandate of prior review of claims. The indemnity bond is intimately related to the possible monetary obligation of the plamtiff, whereas the review requirement is not related directly to any monetary hability inposed on a inalpractice plaintiff. Contra, Hines v. Elkhart Gen. Hosp., 603 F.2d 646, 648 (7th Cir. 1979) (the Indiana medical malpractice screening procedure "is clearly not a mere form or mode for enforcing rights or obligations, but rather the procedure is bound up with those rights and obligations"). 
tended to be bound up with the definition of the rights and obligations of the parties," 65 the state review board laws fail the first two parts of the Miller test.

Under the third part of the Miller test, it is not clear that a federal court's refusal to abide by the state screening requirement "might substantially change the outcome of the hitigation." 66 In the case of pretrial medical malpractice review, the plaimtiff is not totally barred from enforcing his cause of action im the state courts as were the plaintiffs in Woods, Angel, and Guaranty Trust; ${ }^{67}$ the "door-closing" rationale of these cases is not apphicable here. While it is true that a state court could disiniss the suit of a plaimtiff who has not complied with compulsory screening, such a suit is only delayed, not barred absolutely. The plaimtiff may eventually gain entry to the state court for a trial de novo if he hurdles a difficult, time-consuning, and expensive procedural obstacle. ${ }^{68}$

Three questions reinain under the third part of the Miller test: (1) what degree of probability of a substantially different outcoine is necessary; (2) whether in the medical nnalpractice review situation this degree of probability exists; and (3) whether the difference in outcome resulting from a federal court's declining to follow the review requirements would be substantial. The courts have not provided a clear answer to the first question. The Miller test uses the word "inight";69 the Szantay test uses the phrase "would substantially affect." "7o The Byrd decision refers in dicta to the "certainty" and "strong possibility" of a different result. ${ }^{71}$ Nothing on the face of the state review panel statutes mdicates that the outcome of a medical inalpractice case would vary substantially depending on whether or not a panel reviews the claim before trial. ${ }^{72}$ One can only speculate whether the merits of the plam-

65. Byrd v. Blue Ridge Rural Elec. Coop., 356 U.S. 525, 536 (1958).

66. 507 F.2d 308, 314 (6th Cir. 1974).

67. See note 57 supra and accompanying text.

68. The absence of the review process would affect substantially the "character" of malpractice litigation, see text accompanying note 45 supra, as well as "the enforcement of the right as given by the State." Guaranty Trust Co. v. York, 326 U.S. 99, 109 (1945). The differences in "character" and "enforcement," howcver, are not factors in the Miller test and these expressions have not been specifically cinployed in Erie analysis in federal court decisions.

69. See text accompanying note 62 supra.

70. Szantay v. Beech Aircraft Corp., 349 F.2d 60, 64 (4th Cir. 1965).

71. Byrd v. Blue Ridge Rural Elec. Coop., 356 U.S. 525,539 (1958).

72. Judge Rosenn, dissentimg in Edelson v. Soricelli, Nos. 78-2627 \& 79-1012 (3d Cir. Nov. 2, 1979), asserted that federal jurisdiction without prior reference to a review panel would not lead to a result substantially different from tbat which would be reached by state court litigation preceded by the screening process. Judge Rosenn insisted that "[o]nly the forum, not the substantive legal rights, will be different." Id., ship op. at 37.

But see Bernhardt v. Polygraphic Co. of America, 350 U.S. 198 (1956): 
tiff's case (as well as the plaintiff's wallet and patience) will survive the panel hearing and decision. The likelihood of a different result may be increased if there is a review panel decision on the inerits of the plaintiff's clain and that decision is admitted into evidence in subsequent litigation of the claim; the jury might be influenced by the conclusions reached by "the experts." "73 Even if the interposition of a pretrial review procedure or the introduction into evidence of panel findings affects the outcome of the litigation, the question still remains whether the outcome will be changed "substantially." Again, the courts have not explaimed the required degree of substantiahty. If the mandatory review procedure induces the plaimtiff to drop the malpractice claim on which he would prevail in the absence of such a requirement, a substantial difference is obvious. But what of the cases where the review process leads the parties to settlement, or where the introduction into evidence of the panel findings inerely changes the ainount of the jury verdict that would have been reached in the absence of review? Has the outcome of the litigation been substantially changed? ${ }^{74}$ It is impos-

\footnotetext{
If the federal court allows arbitration where the state court would disallow it, the outcome of litigation might depend on the courthouse where suit is brought. For the remedy by arbitration, whatever its merits or shortcomings, substantially affects the cause of action created by the State. The nature of the tribunal where suits are tried is an important part of the parcel of rights behind a cause of action. The change from a court of law to an arbitration panel may make a radical difference in ultimate result.
}

Id. at 203. Bernhardt is distinguishable from the medical malpractice cases in federal courts. In Bernhardt, the parties entered into an employinent contract that contained an arbitration clause. Under the applicable law of Vermont, contracts to arbitrate disputes were revocable. Thus, Vermont law clearly dealt with the rights and obligations of the parties: the right to escape the obligation to arbitrate. Second, arbitration, if allowed, would be the sole method of deciding the merits of the disputants' arguments. The decisions of the medical malpractice review panels are not binding on the parties and the inerits of the parties' claims and defenses may be determmed in a trial de novo.

73. Judge Pettine, writing in Wheeler v. Shoemaker, 78 F.R.D. 218 (D.R.I. 1978), maintained that the admission into evidence in a subsequent jury trial of the screening panel's findings would significantly affect the jury's decisionmaking. "Panel reference is intended to and will, in fact, strongly influence the jury verdict or circumvent jury trial altogether." Id. at 225-26. Juries that have heard the findings of "the court-appointed panel of esteemed professionals who have reviewed all the evidence" will find it difficult to evaluate the evidence independently and reach a conclusion contrary to that reached by the panel. Id. at 226. The Rhode Island statute provides that "[a]ll findings of the panel except as to damages, shall be adinissible as evidence in any action subsequently contimued by the appellant in a court of law." R.I. GEN. LAws $\$ 10-19-8$ (BobbsMerrill Cum. Supp. 1978); see Margolick, supra note 4, at 1, col. 1 \& at 34, col. 3.

74. Guaranty Trust Co. v. York, 326 U.S. 99 (1945), one of the cases from which the third part of the Miller test is derived, suggests that substantiality of difference in outcome occurs with respect to state laws which "intimately affect recovery or non-recovery." Id. at 109 . If this is the standard of substantiality, then only when the review procedure per se permits or prevents a malpractice plaintiff from recovering on his claim can it be said that review might substantially affect the outcoine. In Byrd, the Court noted that "[c]oncededly the nature of the tribunal which tries issues may be important in the enforcement of the parcel of rights inaking up a cause of action or defense, and bear significantly upon achievement of uniforin enforcement of the right." 356 U.S. 
sible to conclude that in all malpractice cases a different result would be reached without the insertion of panel review into the litigation process and, even if so, that this difference in outcome would be substantial.

Assuming arguendo that the imposition of the screening process before trial would substantially alter the result of medical malpractice litigation, there remams under Byrd ${ }^{75}$ and the third part of the Miller test the question whether the state interests in having the federal court refer the malpractice plaimtiff to the screening panel are outweighed by the federal interest in exempting the federal courts from compliance with the state screening requirements. Judge Rosenn, dissenting in Edelson v. Soricelli, ${ }^{76}$ found that impleinentation of the Pennsylvania screening procedure would offend the innportant federal interests in "allowing the full and fair litigation to be decided by the jury," 77 in "maintaining the appearance of strict neutrahty," 78 and in achieving "the goals of the federal courts in convenience and the economical administration of justice."79 Because the Pennsylvania review panel system had been "a resounding flop," 80 the Pennsylvania statute "in its present form advance[d] no legitimate state interest." 81 Thus, the federal interests predoinmated and the federal court should not have followed the state procedure.

525,537 (1958). The Court went on, however, to hold that the federal interest in jury determination of factual questions outweighed any hypothetical difference in outcomes caused by tribunals of different natures. Id. at 538 . The hypothetical change in outcome is similarly outweighed by strong federal interests in the case of medical malpractice cases. See text accompanying notes 91 100 infra. Furthermore, the difference in the nature of the tribunals-federal court versus state review panel-is imtegrated by the parties' option to proceed in ordinary trial court following review. Likewise, the Court in Byrd noted that the probability of different results from a judge's and a jury's decisionmaking was reduced by the federal judge's power to "comment on the weight of [the] evidence and credibility of [the] witnesses, and . . . to grant a new trial if the verdict appears to him to be against the weight of the evidence." 356 U.S. at 540.

75. See note 59 supra and accompanying text.

76. Nos. 78-2627 \& 79-1012 (3d Cir. Nov. 2, 1979) (Rosenn, J., dissenting).

77. Id., slip op. at 37 .

78. Id.

79. Id.

80. Id., slip op. at 11,35 . The majority opinion in Edelson noted that from the 1976 effective date of the Pennsylvania statute, PA. STAT. ANN. tit. 40, $\S$ 1301.301-.606 (Purdon Supp. 19791980), until September 1, 1979, not one panel had met to consider a case and, of the 2,466 claims, only nine had yet reached the hearing stage. "What we confront is an ambitious state program in which the deed has fallen woefully short of the promise." Nos. 78-2627 \& 79-1012, slip op. at 11. See generally Margolick, supra note 4, at 1 , col. 1 .

81. Nos. 78-2627 \& 79-1012, slip. op. at 37-38. Judge Rosenn's argument is fallacious. The ineffectiveness of the means chosen by a state legislature to advance a legitimate interest does not detract from the importance of the interest or make it any less legitimate. See id., slip op. at 16-17 (majority opimion). 
Judge Pettine, writing for the court in Wheeler v. Shoemaker, ${ }^{82}$ rejected the arguinent that a federal court should appoint its own panel in accordance with state law and instead chose to "honor the federal interests in controlling . . . the character, quality and cost of the adjudicatory process in federal court." 83 Under Judge Pettine's analysis, which apparently used the Byrd balancing approach, federal interests outweighed the state interest in reforming medical malpractice hitigation. Judge Pettine strongly suggested that the Rhode Island panel procedure infringed "the federal interest in preserving the jury's role." 84 Rhode Island adopted the panel review procedure "in response to growing frustration with high jury verdicts and settlement of unmeritorious suits under the threat of such verdicts." 85

It is likely that the federal courts' refusal to require plaintiffs to comply with the malpractice screening process would encourage forum shopping and would put resident plaintiffs at a disadvantage vis-a-vis nonresident plaintiffs able to take advantage of diversity jurisdiction. It must be recognized, however, that diversity jurisdiction was created as an alternative to state courts and that the two judicial systenis cannot be identical in every respect. 86 Inherent differences between the courts in such matters as pleadings, discovery, and notions, and variations in judges, courtrooms, and courtroom locations will inevitably lead to forunı shopping between federal and state courts by nonresidents. ${ }^{87}$ Frequently these differences will put resident plaintiffs at a disadvantage as against nonresident plaintiffs. Thus, forum shopping and discrimination, which would exist even if screening panels were not required, cannot be the sole reasons for obhiging federal courts to refer plaintiffs to screening panels as a precondition to bringing suit in federal court. The strong federal interest in protecting diversity jurisdiction, described in the next section, outweighs the problenis of forum shopping and discrimination, ${ }^{88}$ and, bolstered by the supremacy clause of the

82. 78 F.R.D. 218 (D.R.I. 1978).

83. Id. at 229; see Turner, supra note 48 , at 23 .

84. 78 F.R.D. at 225.

85. Id. at 225.

86. "The federal system is an independent system for administering justice to litigants who properly invoke its jurisdiction." Byrd v. Blue Ridge Rural Elec. Coop., 356 U.S. 525,537 (1958). "When, because the plaintiff happens to be a non-resident, [a right to recover] is enforceable in a federal as well as in a State court, the forms and mode of enforcing the right may at times, naturally enough, vary because the two judicial systems are not identic." Guaranty Trnst Co. v. York, 326 U.S. 99, 108 (1945).

87. See Hanna v. Plumer, 380 U.S. 460, 475 (1965) (Harlan, J., concurring); Redish \& Phillips, Erie and the Rules of Decision Act: In Search of the Appropriate Dilemma, 91 HARv. L. Rev. 356, 375-77 (1977); Note, supra note 64, at 691.

88. Judges Rosenn and Pettine recognized that the federal court's refusal to refer a inalpractice case to a state panel or to establish its own panel would give out-of-state plaintiffs an advan- 
Constitution, ${ }^{89}$ prevails over any state interest in the uniforin application of the screening requirement. The third part of the Miller test is not met and, therefore, the Erie doctrine does not require federal courts to yield to the state medical malpractice requirements..$^{90}$

\section{B. The Supremacy of Federal Diversity Jurisdiction.}

Railway Co. v. Whitton's Administrator ${ }^{91}$ is the leading case for the principle that federal courts must protect their diversity jurisdiction against state statutes that attempt to hmit a state-created cause of action to state courts. A Wisconsin statute creating a cause of action for wrongful death contamed a provision that such actions were to be brought only im a Wisconsin state court. The Supreme Court held that the statute's forum limitation provision was not binding on a federal diversity court:

In all cases where a general right is thus conferred, it can be enforced in any Federal court within the State having jurisdiction of the parties. It cannot be withdrawn from the cognizance of such Federal court by any provision of State legislation that it shall only be enforced in a State court. The statutes of nearly every State provide for the institution of numerous suits, such as for partition, foreclosure, and the recovery of real property in particular courts and in the counties where the land is situated, yet it never has been pretended that limitations of this character could affect, im any respect, the jurisdiction of the Federal court over such suits where the citzenship of one of the parties was otherwise sufficient. Whenever a general rule as to property or personal rights, or injuries to either, is established by State legislation, its enforcement by a Federal court in a case between proper parties is a inatter of course, and the jurisdiction of the court, im such case, is not subject to State limitation. ${ }^{92}$

tage over in-state plaintiff, would encourage forum shopping, and would frustrate the state objective in stabilizing health care and liabihty insurance costs. Citizens of the forum state, however, in contrast to out-of-state residents, "have the ability to reform their procedures through their political processes," and the federal interests im protecting diversity jurisdiction outweigh the concerns reflected in the Erie doctrine. Edelson v. Soricell, Nos. 78-2627 \& 79-1012, slip op. at 34 (3d Cir. Nov. 2, 1979) (Rosenn, J., dissenting); Wheeler v. Shoeinaker, 78 F.R.D. 218, 228-29 (D.R.I. 1978).

89. U.S. Const. art. VI, cl. 2.

90. The Erie issues involved in these medical inalpractice cases would, of course, become inoot if Congress abohished the diversity of citizenship jurisdiction of the fcderal courts. Congressinan Charles E. Bennett of Florida recently introduced a bill to "abolish diversity of citizenship as a basis of jurisdiction of Federal district courts." H.R. 130, 96th Cong., 1st Sess. (1979).

91. 80 U.S. (13 Wall.) 270 (1871).

92. Id. at 286; see Hyde \& Oglesby v. Stone, 61 U.S. (20 How.) 170 (1857). "[T]his court has repeatedly decided that the jurisdiction of the courts of the United States over controversics between citizens of different States cannot be inpaired by the laws of the states, which prescribe the unodes of redress in their courts, or which regulate the distribution of their judicial power." Id. at 175. See generally U.S. CoNST. art. III, §§ 1-2; art. VI, cl. 2; 28 U.S.C. § 1332 (1976). 
The Whitton rule lias found application in two particular kinds of cases: suits against political subdivisions and suits relating to decedents' estates. The inost influential decision in the former category is Markham v. City of Newport News. ${ }^{93}$ Markham concerned a Virginia statute that provided that suits against Virginia cities could be brought only in Virginia state courts. The Court of Appeals for the Fourth Circuit held that this limitation could not deprive a federal court of diversity jurisdiction. "[W] henever a state provides a substantive right and a remedy for its enforcennent in a judicial proceeding in any state court, a judicial controversy involving the right may be adjudicated by a United States District Court if it has jurisdiction under the Constitution and laws of the United States."94 Attempts by the state to limit suits against political subdivisions or governmental agencies to a particular category of state court are likewise unavailing to deprive a federal court of its diversity jurisdiction: 95

Where . . . a cause of action exists in a state, albeit the state court in which it may be enforced is limited, a federal court deciding the same cause of action would presumably reach a result identical to that reached in the state court. The difference is purely in the means of reaching that result.96

Although the federal courts do not have jurisdiction over "proceedings purely of probate character,"97 federal diversity jurisdiction "is not subject to limitations or restraint by state legislation establishing courts of probate and giving then jurisdiction over similar matters." 98 Federal diversity courts may "exercise original jurisdiction ... in favor of creditors, legatees and heirs to establisl their claims"99 even though "the statutes of the State undertake to give to state probate courts exclusive jurisdiction over all matters concerning the settlement of accounts of executors and administrators in the distribution of estates." 100 There are certain causes of action, then, that can be lieard by federal diversity courts despite state laws that purport to limit suits based on such causes of action to a specialized probate court.

93. 292 F.2d 711 (4th Cir. 1961).

94. Id. at 716; see Cowles v. Mercer County, 74 U.S. (7 Wall.) 118 (1868); Grady County v. Dickerson, 257 F.2d 369 (5th Cir. 1958); Schultz v. Greater New Orleans Expressway Comm'n, 250 F. Supp. 89 (E.D. La. 1966).

95. Sherman v. Ulmer, 201 F. Supp. 660 (E.D. Pa. 1961).

96. Id. at 662 .

97. Waterman v. Canal-Louisiana Bank \& Trust Co., 215 U.S. 33, $43-44$ (1909).

98. Id. at 43.

99. Id.

100. Id. at 44. The federal court, however, "cannot seize and control the property which is in possession of the state court." Id. See Markham v. Alleu, 326 U.S. 490, 494 (1946); Akin v. Louisiana Nat'l Bank of Baton Rouge, 322 F.2d 749 (5th Cir. 1963); Monogram Indus., Inc. v. Zellen, 467 F. Supp. 122 (D. Mass. 1979). 
Because the cases applying the Whitton rule involve state attempts to confine causes of action to particular state courts, the applicability of the principle to compulsory medical inalpractice screening may depend on whetler the screening panels are state courts for purposes of the rule. ${ }^{101}$ Because decisions employing the Whitton rule do not indicate what constitutes a "state court," it is necessary to examme another area of federal law for such criteria. Removal of cases from state to federal courts is an area of federal law that provides standards for determining which tribunals and proceedings constitute state courts. The federal removal statute permits a defendant to remove to a federal district court "any civil action brought in a State court of which the district courts of the United States have original jurisdiction."102 Commissioners of Road Improvement District No. 2 v. St. Louis Southwestern Railway ${ }^{103}$ supports the proposition that state medical malpractice screening panels are state courts. Under an Arkansas statute, the commissioners of a road district submitted plans for improvemcnts and estimates of their cost to the county court. The court then appointed three assessors to estimate the amount by whicl an improvement would enhance neighboring real estate, as well as any damages that might be sustained by reason of the improvement. The assessors noted in a book the amounts of benefits and damages assessed. The commissioners were required to file the assessment in the county court, at which time the county court clerk would publish notice of the assessinents and call upon persons aggrieved by any assessment to appear before the county court. The county court would then hold a liearing and determine the justness of any assessment of benefits or damages; this court was authorized to adjust any assessment upon a proper showing by the landowner. Either the landowner or the commissioners could appeal from the judgment of the county court to the circuit court, the Arkansas court of general jurisdiction. Upon appeal, the circuit court would try the case de novo. In Southwestern Railway, the landowner, a railroad coinpany, filed a petition for removal on the day before the scheduled hearing before the county court.

The Supreine Court, faced with the question whetlier the Arkansas county court was a "state court" for purposes of removal to federal court, concluded that it was a state court because "the proceeding

101. Judge Rosenn, dissenting in Edelson v. Soricelli, Nos. 78-2627 \& 79-1012 (3d Cir. Nov. 2, 1979), and Judge Pettine, writing in Wheeler v. Shoemaker, 78 F.R.D. 218 (D.R.I. 1978), argued that the respective state screening panels constituted state courts that would deprive federal courts of their diversity jurisdiction if federal judges were obliged to refer medical malpractice plaintifs to such panels. See note 113 infra.

102. 28 U.S.C. $\$ 1441$ (a) (1976).

103. 257 U.S. 547 (1922). See also Searl v. School Dist. No. 2, 124 U.S. 197, 199-200 (1888). 
before it ha[d] all the elements of a judicial controversy . . ., to wit, adversary parties and an issue which the claim of one of the parties against the other capable of pecuniary estimation, is stated and answered in some form of pleading, and is to be determined."104 To support its conclusion, the Court noted that the commissioners were the plaintiffs and the landowners were the defendants in this suit. The book of assessinent and the landowners' written objections to it constituted the pleadings; and oral evidence was to be heard on the issues.

Medical malpractice screening panels are analogous to the county court in Southwestern Railway. The state statutes often provide for "pleadings" 105 from the claimant and the health care provider. The proceeding before the panel is clearly "adversary and inter pares."106 The panel, like the county court, receives written and oral evidence from the parties. The findings of the panel, like the judgment of the county clerk, nay be rejected by the parties, and either party may obtain a trial de novo on the issues before a court of general jurisdiction. The medical malpractice screening panels, then, seem to meet the criteria of a "state court" for purposes of removal. Such factors as the availability of discovery and the panel's subpoena power reinforce this conclusion. ${ }^{107}$

Recent cases have advocated a functional approach for determining whether a state tribunal is a state court under the removal statute. ${ }^{108}$ It is necessary to (1) evaluate the functions, powers, and procedures of the state tribunal; (2) consider these factors along with the respective state and federal interests in the subject matter and in the provision of a foruin; 109 and (3) determine the "locus of traditional ju-

104. 257 U.S. at 557.

105. See note 22 supra and accompanying text.

106. 257 U.S. at 559 .

107. See notes 16-30 supra and accompanying text.

108. See Floeter v. C.W. Transp., Inc., 597 F.2d 1100 (7th Cir. 1979); Volkswagen de Puerto Rico, Inc. v. Puerto Rico Labor Relations Bd., 454 F.2d 38 (1st Cir. 1972); Tool \& Die Makers Lodge No. 78 v. General Elec. Co., 170 F. Supp. 945 (E.D. Wis. 1959). These cases involved coinplaints alleging violations of collective bargaining agreeinents between employees' associations and employers. The complaints were filed before the appropriate state labor relations boards. The cases held that the boards were state courts for purposes of removal to federal court.

109. Floeter v. C.W. Transp., Inc., 597 F.2d 1100, 1102 (7th Cir. I979). In Floeter and the two other cases advocating the functionaI approach, see note 108 supra, it is important to note that the litigation in question-suits for violation of collective bargaining agreements-could have been brought originally in federal court without respect to the amount in controversy and without regard to the citizenship of the parties. 29 U.S.C. $\$ 185$ (a) (1976). This statutory provision for federal court jurisdiction indicates a special federal interest in the subject matter of the hitigation. See Floeter v. C.W. Transp., Inc., 597 F.2d at 1102; Volkswagen de Puerto Rico, Inc. v. Puerto Rico Labor Relations Bd., 454 F.2d 38, 44 (Ist Cir. 1972). This federal interest in the enforcement of collective bargaining agreements is not present in actions for medical malpractice. 
risdiction" over the type of action prosecuted before the tribunal. 110

Under this functional approach, the medical malpractice screening panels have many of the functions, powers, and procedures of a court: the confrontation of adversaries, the parties' presentation of evidence to factfinders, the right of discovery, the panel's subpoena power, and the panel's findings on hability and damages. ${ }^{111}$ In addition, the type of action brought by a malpractice plaintiff-neghigence-has its traditional locus of jurisdiction in a court of law. Finally, the federal imterest in providing a federal forum to plaintiffs who satisfy the jurisdictional requirements of diversity of citizenship and amount in controversy (the Whitton principle) outweighs the state's mterest in reducing the amount of medical malpractice claims to reach the courts. The state's interest in providing a "convenient and expeditious tribunal to adjudicate the rights and interests of parties" to a malpractice action "is not substantially greater than the state's interest im mamtaining any court system and does not outweigh the defendant's right to remove the action to federal court." 112 Thus, the medical malpractice screening panels are state courts for purposes of removal. If this definition of state court is apphicable to the Whitton principle, it would prohibit states froin compelling federal courts to require pretrial panel review of medical inalpractice claims that plamtiffs seek to litigate in federal court. ${ }^{113}$ A federal court should not be hampered in the exercise of its

110. Volkswagen de Puerto Rico, Inc. v. Puerto Rico Labor Relations Bd., 454 F.2d 38, 44 (1st Cir. 1972).

111. See text accompanying notes $16-30$ supra.

112. Floeter v. C.W. Transp., Inc., 597 F.2d 1100, 1102 (7th Cir. 1979).

113. Two federal judges have argued that a federal court's reference of a medical malpractice claim to a state-created review panel would run afoul of the supremacy of the congressional grant of federal diversity jurisdiction. Judge Rosenn argued in dissent in Edelson v. Soricelli, Nos. 782627 \& 79-1012 (3d Cir. Nov. 2, 1979), that the Pennsylvania review board was a "judicial entity artfully draped in non-judicial garb," id., slip op. at 24, and "a surrogate for the state court," id., slip op. at 29. Pennsylvania had not sought to ehminate the patient's right to recover for medical malpractice but had sought to channel all plaimtiffs to a "special state judicial forum," the screening panel. Pennsylvania's attempt to direct malpractice suits to the panel should not be permitted to deprive a federal court of jurisdiction. Id., ship op. at 24.

Judge Pettine pointed out in Wheeler v. Shoemaker, 78 F.R.D. 218 (D.R.1. 1978), that the Rhode Island legislature "preserved all the elements of and defenses against the common law malpractice action, including trial by a common law court; it merely altered the initial forinat of the trial." $I d$. at 221. He concluded that the malpractice mediation panel was "essentially an adjunct of state court," and that reference by a federal court to such a panel would defeat the congressional creation of diversity jurisdiction. Id. at 222.

Courts espousing the majority view have attempted to distinguish Wheeler on the grounds that the Rhode Island statute in Wheeler inandates reference to a mediation panel after the action has been filed in state court. In statutes under consideration by the majority-view courts, the medical inalpractice claimant inust proceed to a mediation panel before he brings an action in court. See Woods v. Holy Cross Hosp., 591 F.2d 1164, 1169 n.7 (5th Cir. 1979); Seoane v. Ortho Pharmaceuticals, Inc., 472 F. Supp. 468, 471 (E.D. La. 1979); $c$. Hines v. Elkhart Gen. Hosp., 465 
original jurisdiction by the states' assertion of exclusive jurisdiction in state courts specializing in medical malpractice. ${ }^{114}$

\section{CONCLUSION}

The Erie doctrine, as developed and refined by Erie's progeny, does not counpel a federal diversity court to dismiss a medical malpractice suit by a plaintiff who has not comphed with a state coinpulsory screening statute. The screening panel procedure is not a basic right or obhgation, nor is it intimately bound up with one. ${ }^{115}$ Colnphance with the screening procedure has only a conjectural effect on the ultimate determination whether the health care provider is liable to the plaintiff for professional negligence. The conditions that Erie sought to prevent-forum shopping and discrimination against resident plaintiffsare likely to result from the federal courts' freedom to ignore the state screening panel requirements. The frustration of these twin aims of Erie is counterbalanced by the strong federal interest, expressed in the Whitton principle, of denying state legislatures the power to use statecreated judicial proceedings to obstruct federal diversity jurisdiction. The ability of the states to condition the enforceability of a claim upon pretrial review by a state court would constitute an impermissible state regulation of access to federal courts. The Whitton principle, by itself and as an element weighing heavily in the Byrd balance, frees the federal courts from state mandatory screening requirements.

John H. Pavloff

F. Supp. 421, 424-25 (N.D. Ind.), affd, 603 F.2d 646, 648 (7th Cir. 1979). The importance of this distinction under either the Erie doctrine or the Whitton rule is unclear. Whether or not a claim has been filed has little bearing on whether the screening process is intimately bound up with rights or obligations or whether the screening panel itself is a state court.

114. Contra, Himes v. Elkhart Gen. Hosp., 465 F. Supp. 421 (N.D. Ind.), affd, 603 F.2d 646 (7th Cir. 1979). "[T]lis statutory condition of precedent to the filing of malpractice claims within the diversity jurisdiction of this Court does not infringe upon this Court's jurisdiction." $465 \mathrm{~F}$. Supp. at 425; see Turner, supra note 48, at 22-23. Turner, and the cases cited in note 113 supra, distinguish state malpractice statutes that provide for review prior to filing a lawsuit from those in which review occurs after commencement of the lawsuit. As to the former, there is no worry that "the integrity of the federal judicial system is threatened by the wholesale adoption of state practices." Id. Under the latter type of statute,

the burden that would be imposed on the federal courts by conforining would be substantial. . . . Referral of the action back to a state-run arbitration panel would constitute an abdication by the federal court, while building an arbitration system from the ground Id. up, witlout legislative guidance, would cause a serious drain on the court's resources.

115. See text accompanying note 54 supra. 